\title{
PEMANFAATAN RUANG TELAGA PADA TRADISI SEDEKAH BUMI DESA CERME KIDUL, KECAMATAN CERME, KABUPATEN GRESIK
}

\author{
Slamet ${ }^{1}$,Jenny Ernawati ${ }^{2}$,Agung Murti Nugroho ${ }^{3}$ \\ ${ }^{1}$ Dinas Pekerjaan Umum Cipta Karya dan Tata Ruang Provinsi Jawa Timur. \\ ${ }^{2}$ Program Magister Arsitektur Lingkungan Binaan, Universitas Brawijaya. \\ ${ }^{3}$ Program Magister Arsitektur Lingkungan Binaan, Universitas Brawijaya. \\ E-mail: slam 2112@yahoo.com; iny23ern@gmail.com; sasimurti@yahoo.co.id
}

\begin{abstract}
ABSTRAK
Aspek tradisi yang semakin memudar, pengaruh tradisi sebagian besar masyarakat Desa Cerme Kidul melaksanakan tradisi Sedekah Bumi, apabila tidak melaksanakan tradisi Sedekah Bumi mereka meyakini akan terjadi sesuatu hal yang tidak diinginkan. Tujuan tradisi Sedekah Bumi adalah meminta doa restu kepada Tuhan Yang Maha Esa dan kepada nenek moyang supaya semua urusan dilancarkan dan sebagai rasa syukur atas rejeki yang diberikan berupa panen raya, serta upaya untuk melestarikan budaya leluhur. Metode yang digunakan dalam penelitian ini adalah metode kualitatif, teori yang digunakan sebagai landasan penelitian ini adalah Environment Behavior Study, di dalam tradisi Sedekah Bumi di Telaga Desa Cerme Kidul terkandung makna silaturrahmi diantara warga tidak memandang suku, agama dan tingkatan sosial, Tradisi Sedekah Bumi adalah salah satu tradisi yang masih melekat pada masyarakat Desa Cerme Kidul. Tradisi tersebut dilaksanakan ketika selesai panen padi. Tradisi ini dilaksanakan di Punden Telaga.
\end{abstract}

Kata Kunci : punden telaga, warisan budaya, tradisi budaya.

\section{Pendahuluan}

Desa Cerme Kidul merupakan permukiman yang berciri khas agraris, dengan mata pencaharian sebagian besar penduduk adalah petani. Penggunaan lahannya didominasi oleh lahan pertanian, lahan tambak dan permukiman. Kehidupan masyarakat bergantung pada hasil lahan pertanian dengan sistem sawah tadah hujan. Ladang dan sawah milik masyarakat mengelilingi kawasan permukiman.

Tradisi sedekah bumi sebagai wujud syukur kepada Tuhan Yang Maha Esa dan simbol kerukunan warga di Desa Cerme Kidul masih dilakukan masyarakat hingga sekarang. Sedekah bumi merupakan suatu wujud kearifan lokal dalam bentuk upacara atau tradisi sebagai wujud komunikasi antara manusia dengan alam (Wibowo et al, 2012).

Dalam tradisi sedekah bumi ini terdapat berbagai macam kesenian maupun ritual tradisional yang menjadi rangkaian kegiatan. Penggunaan Telaga sebagai tempat kegiatan Sedekah Bumi karena memiliki historis yang penting bagi masyarakat setempat. Desa Cerme Kidul mempunyai keunikan dalam budaya Sedekah Bumi yaitu diadakan di bawah pohon Lom yang diyakini oleh warga setempat sebagai Pepunden Telaga, menurut cerita dari Bapak Usman sesepuh warga desa cerme kidul yang lahir pada tanggal 30 Mei 1941 ini, dulu di 
telaga ini dikuasai oleh seorang pendekar yang bernama Joko Umbaran (mbah Dermo) yang berhasil mempertahankan diri dari serangan musuh antar pendekar pada jaman dulu, karena masyarakat Desa Cerme Kidul sejak jaman nenek moyang dulu sudah melakukan Tradisi Sedekah Bumi di telaga, yang setiap harinya telaga ini sangat bermanfaat bagi kehidupan warga Desa Cerme Kidul karena telaga ini sebagai penampungan air saat musim hujan tiba, air telaga digunakan untuk pengairan sawah, tambak dan kebutuhan sehari-hari.

Maka dari itu sebagai ungkapan rasa syukur setelah panen raya yang berlimpah upacara Tradisi Sedekah Bumi ini dilaksanakan setiap tahun, tradisi Sedekah Bumi di Telaga yang dihadiri oleh warga setempat dengan membawa bermacam-macam makanan, lauk pauk, ayam panggang serta buah-buahan.

Setelah selesai acara Sedekah Bumi dilanjutkan dengan hiburan, hiburan setiap tahunnya berganti-ganti sesuai dengan keinginan warga, pada tahuntahun sebelumnya hiburannya hanya satu pilihan yaitu wayang kulit namun dengan berjalannya waktu akhirnya wayang sudah mulai tergeser, sekarang hiburannya diganti dengan Orkes Dangdut.

Kegiatan ini menunjukkan adanya keterkaitan erat antara manusia baik dengan Tuhan, alam dan sesamanya. Interaksi sosial yang terjadi pada ritual tradisional ini menimbulkan perpaduan kehidupan sosial budaya masyarakat Desa Cerme Kidul, sehingga aktivitas dan perilaku masyarakat menjadi faktor penting pembentuk konsep ruang pada skala permukiman. Perilaku, kegiatan, dan nilai-nilai yang ada dalam masyarakat menjadi pembentuk ruang yang memberikan identitas pada permukiman yang merupakan perwujudan arsitekturnya. Arsitektur merupakan ruang fisik untuk aktivitas manusia, yang memungkinkan pergerakan manusia dari satu ruang ke ruang lainnya, menciptakan tekanan antara ruang dalam bangunan dan ruang luar (Laurens, 2004).

Penelitian ini akan difokuskan pada Telaga ketika dilakukan tradisi sedekah bumi masyarakat desa Cerme Kidul, sehingga diketahui pemanfaatan ruang yang terjadi berdasarkan budaya masyarakatnya. Melalui pemanfaatan ruang ini akan diketahui tempat yang dipergunakan, waktu, dan pelaku berdasarkan ritual yang dilakukan serta budaya yang mengikutinya berdasarkan teori tentang behavior setting yang dikemukakan oleh Barker.

\section{Bahan dan Metode}

\subsection{Landasan Teori}

Dalam kamus Besar Bahasa Indonesia disebutkan bahwa ritual adalah tata cara atau kegiatan tertentu dalam upacara keagamaan yang berhubungan dengan kejiwaan rohani/ batin. Arimbawa (2010) menyatakan bahwa pada masyarakat tradisional, aktivitas masyarakat selalu berkaitan dengan dua kegiatan utama yaitu yang bersifat sakral (berkaitan dengan agama) dan kegiatan yang bersifat profan (berkaitan dengan kegiatan sosial masyarakat). Sehingga kegiatan sedekah bumi dapat dikategorikan sebagai ritual, karena melibatkan kejiwaan pelaku baik secara sakral (berhubungan dengan ke-Tuhanan) maupun profan (berhubungan dengan kegiatan sosial masyarakat) dalam pelaksanaannya.

Pelaksanaan tradisi ini melibatkan berbagai pelaku, dan kegiatan, sehingga menghadirkan ruang pada lingkungan tempat kegiatan dilangsungkan sesuai dengan perilaku penggunanya. Menurut Zeisel (1981) Behavior setting 
dapat diartikan secara sederhana sebagai suatu interaksi antara suatu kegiatan dengan tempat yang spesifik. Dengan demikian Behavior setting mengandung unsur-unsur sekelompok orang tersebut, tempat dimana kegiatan tersebut dilakukan, serta waktu spesifik saat kegiatan tersebut dilaksanakan. Contoh: di dalam suatu setting tempat ibadah, rumah maupun permukiman.

Lebih lanjut Zeisel (1981) menyatakan, bahwa teori-teori dalam setting dan perilaku menjelaskan terdapatnya hubungan timbal balik dan saling mempengaruhi satu sama lain. Karakteristik fisik setting dapat mempengaruhi hubungan antar orang atau kelompok dan sebaliknya.

Pola perilaku manusia berkaitan dengan tatanan fisik lingkungannya yang disebut dengan behavior setting. Behavior setting didefinisikan oleh Barker dalam Zeisel (1981) sebagai berikut:

a. Terdapat aktivitas yang berulang, berupa suatu pola perilaku (standing patern behavior). Pola perilaku dapat terdiri atas lebih dari satu pola perilaku ekstra individual. Hal ini menunjukan bahwa pola perilaku tidak bergantung pada pelaku atau objek melainkan lebih kepada konfigurasi secara menyeluruh.

b. Milieu, yaitu merupakan pola perilaku yang merujuk pada batas fisik dan temporal dari sebuah setting. Setiap Behavior setting memiliki perbedaan pada kondisi fisik dan temporalnya.

c. Synomorphic, yaitu berarti adanya hubungan atau interaksi antara pelaku dan milieunya.

d. Temporal, merupakan batasan waktu pada periode tertentu.

\subsection{Metode Penelitian}

Penelitian ini menggunakan metode deskriptif kualitatif yang bertujuan untuk menyajikan gambaran secara lengkap tentang ruang Tradisi Sedekah Bumi di Telaga Desa Cerme Kidul Kecamatan Cerme Kabupaten Gresik yang meliputi beberapa aspek yaitu ruang dan masyarakat yang berada di dalamnya.

Data diperoleh dengan melakukan observasi dan wawancara. Observasi dilakukan untuk memperoleh data menyeluruh mengenai rangkaian kegiatan sedekah bumi yang dilakukan pada Telaga. Wawancara dilakukan untuk mengetahui makna dan kandungan dari perilaku yang dilakukan pada kegiatan sedekah bumi tersebut.

Setelah data terkumpul, dilakukan penyusunan secara sistematis untuk selanjutnya dianalisis secara deskriptif, sehingga diketahui pemanfaatan ruangnya berdasarkan setting perilaku pengguna ruang beserta budaya yang mengikutinya.

\section{Hasil Dan Pembahasan}

\subsection{Gambaran Umum Lokasi Studi}

Gresik adalah salah satu kota pantai utara Pulau Jawa yang memiliki keistimewaan berupa kota multi etnis, sehingga meninggalkan artefak arsitektur yang unik, khas dan beragam. Hal ini disebabkan oleh masuknya berbagai suku bangsa dengan beragam kebudayaan sesuai dengan etnis yang ada. Penduduk Gresik mayoritas beragama Islam, dan mempunyai tempat Wisata Religi yaitu Makam Sunan Giri yang terletak di sebelah selatan dari Pemerintahan Kabupaten Gresik. Berdasarkan cerita dari para sesepuh terdahulu, Cerme merupakan salah satu persinggahan para pendekar-pendekar dan prajurit-prajurit pada masa 
kerajaan Majapahit menuju Kerajaan Giri dan Keraton Sidayu untuk kepentingan pemerintahan pada zaman Majapahit. Sejarah nama Cerme berasal dari kata dalam bahasa Jawa "ancer-ancer rame" yang dalam bahasa Indonesia berarti "diperkirakan ramai". Namun ada juga yang mengartikan "tanda-tandanya ramai", karena kata ancer-ancer dipergunakan untuk menunjukkan arah dan tempat.

Desa Cerme Kidul mempunyai keunikan dalam budaya Sedekah Bumi yaitu diadakan di bawah pohon Lom yang diyakini oleh warga setempat sebagai Pepunden Telaga, sumber: Bapak Usman sesepuh desa cerme kidul, dulu di telaga ini dikuasai oleh seorang pendekar yang bernama Joko Umbaran yang berhasil mempertahankan diri dari serangan musuh antar pendekar pada jaman dahulu. Masyarakat Desa Cerme Kidul sejak jaman dahulu sudah melakukan Tradisi Sedekah Bumi di telaga, setiap harinya telaga ini sangat bermanfaat bagi kehidupan warga Desa Cerme Kidul untuk penampungan air pada saat musim hujan, air telaga digunakan untuk pengairan pertanian, tambak dan kebutuhan sehari-hari.
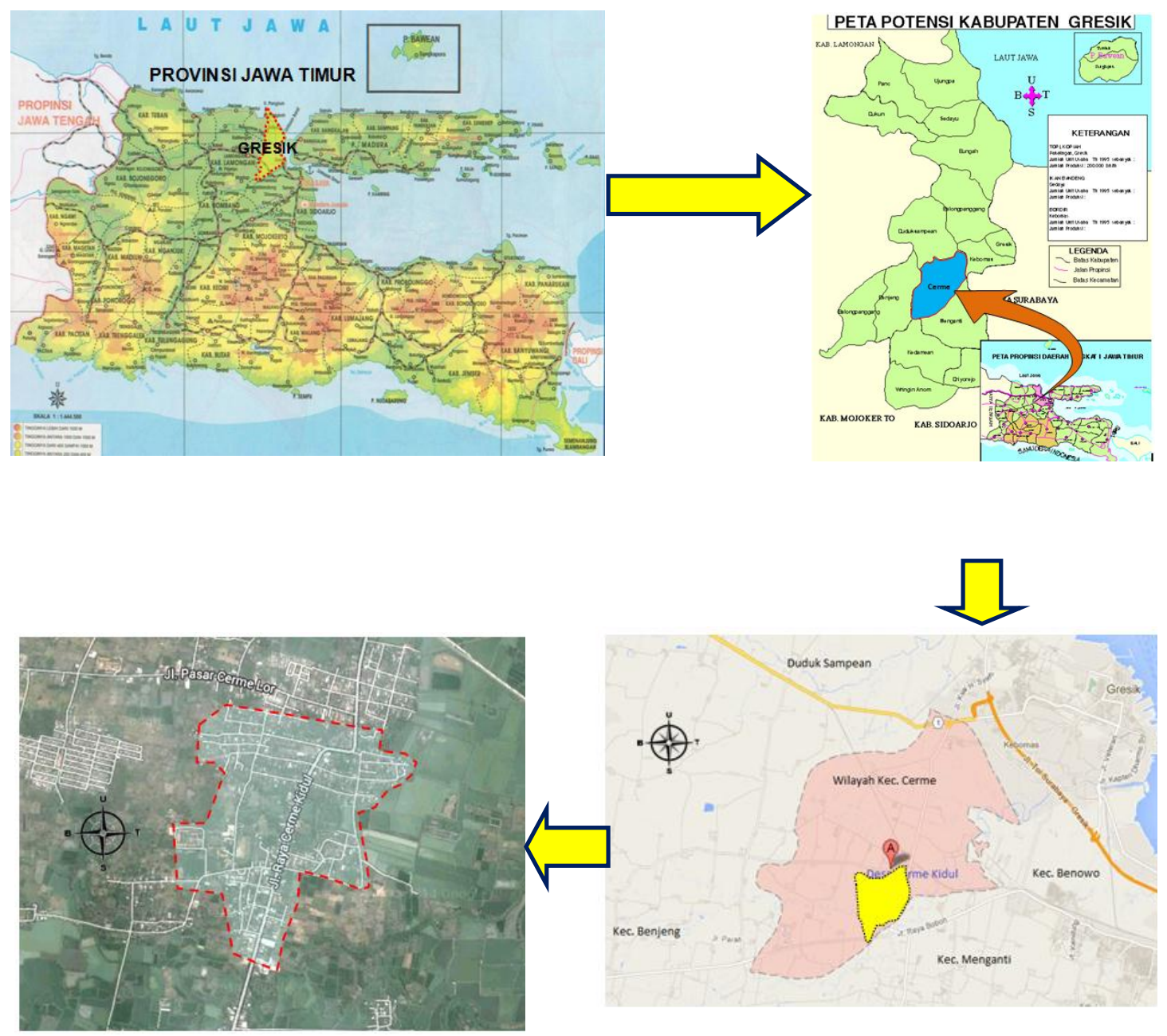

Gambar 1. Lokasi Studi Desa Cerme Kidul Kecamatan Cerme Kabupaten Gresik - Jawa Timur Sumber: google (2014) 


\subsection{Telaga}

Telaga merupakan tempat penampungan air hujan pada saat musim penghujan (rendeng), luas telaga kurang lebih $10.000 \mathrm{~m}^{2}$ debit air yang dapat ditampung kurang lebih $15.000 \mathrm{~m}^{3}$, setiap hari air telaga dimanfaatkan oleh masyarakat sebagai pengairan sawah oleh para petani yang menggunakan pompa air untuk dialirkan ke sawah masing-masing, sebagian warga juga memanfaatkan air telaga untuk berternak ikan, salah satu warga ada juga yang memanfaatkan lahan di pinggir telaga sebagai tempat berkebun.
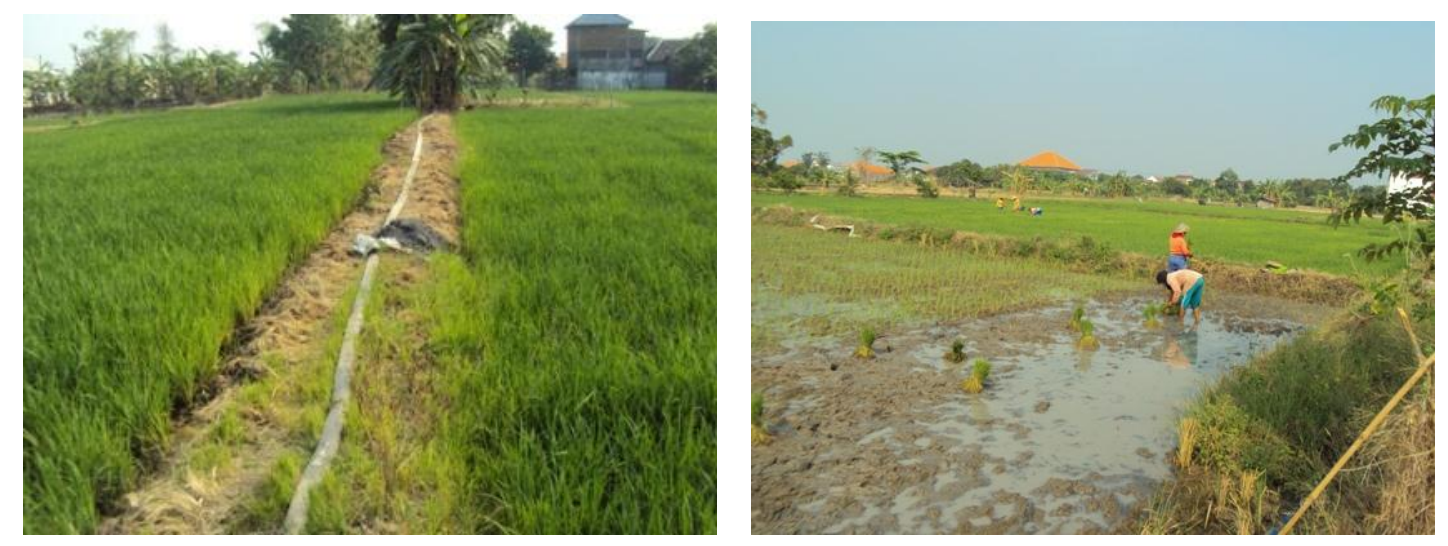

Gambar 2. Warga di Sawah memanfaatkan air Telaga sebagai pengairan sawah.
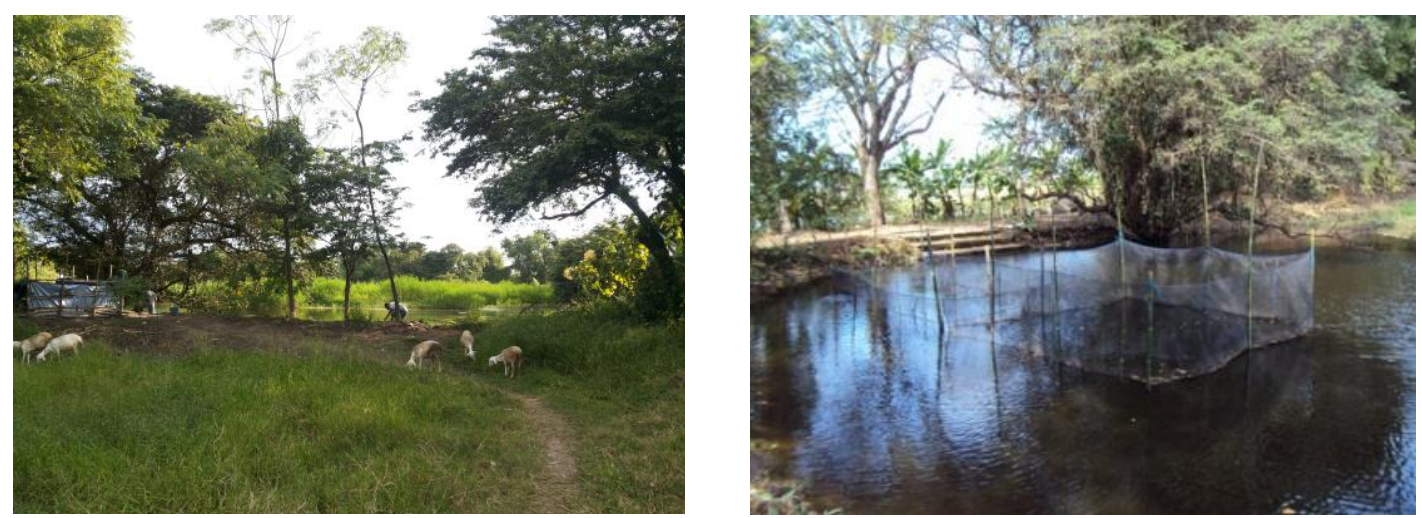

Gambar 3. Warga di Telaga Menggembala Hewan Ternak dan Berternak Ikan

Di telaga ini terdapat banyak macam pohon diantaranya ada pohon sono, pohon kelampis, pohon pisang, pohon bambu dan pohon lom. Nah pohon lom inilah yang mendominasi area telaga karena pohon lom ini konon ceritanya adalah pohon yang usianya sudah ratusan tahun yang sampai sekarang masih dipercaya ada yang menunggu, diantara pohon lom yang terdapat di pinggir telaga sebelah timur merupakan pohon lom yang paling besar, menurut cerita sesepuh Desa Bapak Usman yang lahir pada tanggal 30 Mei 1941 ini merupakan Punden Telaga.

Maka setiap ada orang yang hendak melaksanakan hajatan memberi sesaji ke Punden Telaga agar dalam pelaksanaan acara hajatan diberi kelancaran dan keselamatan. Menurut Ibu Lastri warga RT. 2 / RW. 2 ini dulu pernah ada cerita orang yang punya hajatan menikahkan putranya lupa atau tidak memberi sesaji ke Punden Telaga akhirnya kedua pengantin meninggal dunia karena kecelakaan, hal inilah masyarakat akhirnya mengambil kesimpulan bahwa 
ternyata kalau tidak memberi sesaji ke Punden Telaga maka akan terjadi sesuatu yang buruk pada mereka (sial), akhirnya setiap akan punya hajatan harus memberi sesaji ke Punden Telaga bagi yang masih mempercayainya. Telaga selain itu juga digunakan sebagai tempat menggembala kambing karena lahanya yang sangat luas dan tempat memancing ikan oleh sebagian masyarakat.
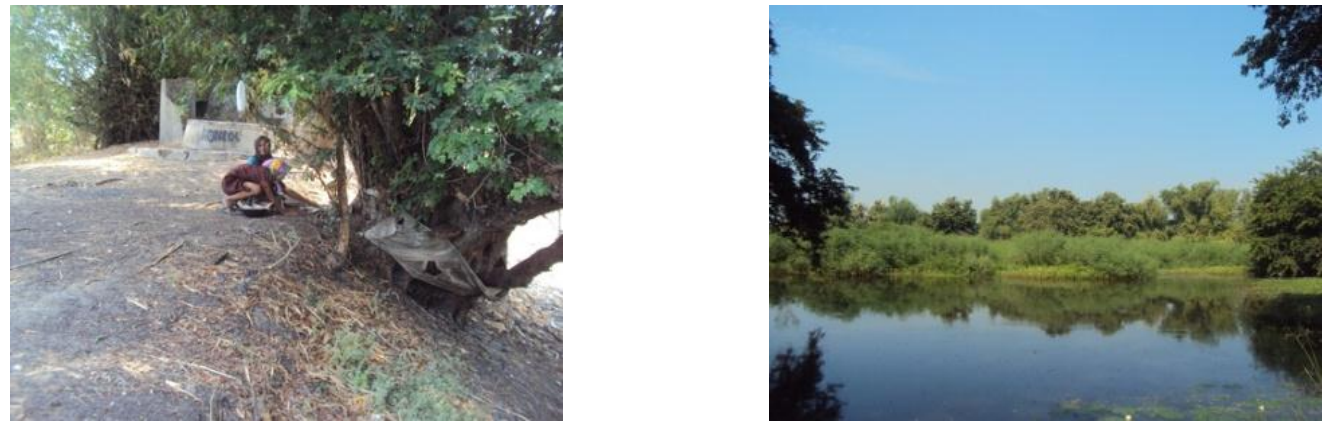

Gambar 4. Telaga dan Warga yang sedang memberi sesaji pada Punden Telaga (Pohan Lom).

\subsection{Tujuan Upacara Sedekah Bumi}

Tujuan diadakan Upacara Tradisi Sedekah Bumi di Punden Telaga adalah untuk menghormati Punden Telaga yang telah menjaga warga Desa Cerme Kidul dari marabahaya. Jika Sedekah Bumi tidak diadakan warga yang masih mempercayai kekeramatan Punden Telaga khawatir akan terjadi hal-hal yang tidak diinginkan pada mereka. Selain itu juga sebagai upaya untuk melestarikan budaya leluhur.

Kegiatan diawali dengan warga membawa tumpeng dengan lauk pauknya seperti ayam panggang, bandeng goreng, tempe tahu, ada juga yang membawa buah-buahan dari hasil panen serta sesaji takir yang berisi telor ayam kampung dan kolo pendem.

Pelaksanaan tradisi Sedekah Bumi dimulai pada pukul 11.00 WIB bertempat di Punden Telaga Desa Cerme Kidul, yang mengikuti acara Sedekah Bumi yaitu seluruh warga masyarakat Desa Cerme Kidul baik laki-laki dan perempuan yang masih meyakini adanya roh-roh penunggu telaga (Punden Telaga) orang tua dan anak-anak, Perangkat Desa, Bapak Kepala Desa dan Juru Kunci Punden Telaga (sesepuh desa). Hadirnya peserta yang terdiri dari masyarakat, tokoh desa, juru kunci, dan pejabat pemerintahan setempat menjadi tanda bahwa Sedekah Bumi merupakan sarana harmonisasi. Artinya sebuah tradisi yang bukan hanya mendamaikan antara kehidupan jasmani dan rohani, antara dunia manusia dengan dunia roh, tetapi juga menjadi penyelaras dalam kehidupan sosial budaya. Dalam prosesi Sedekah Bumi peserta berkumpul bersama tanpa ada sekat-sekat dalam kelas sosial dan status sosial, tanpa ada perbedaan agama dan keyakinan, golongan maupun partai. Nuansa kedamaian, humanitas dan familiar sangat kental terasa. 

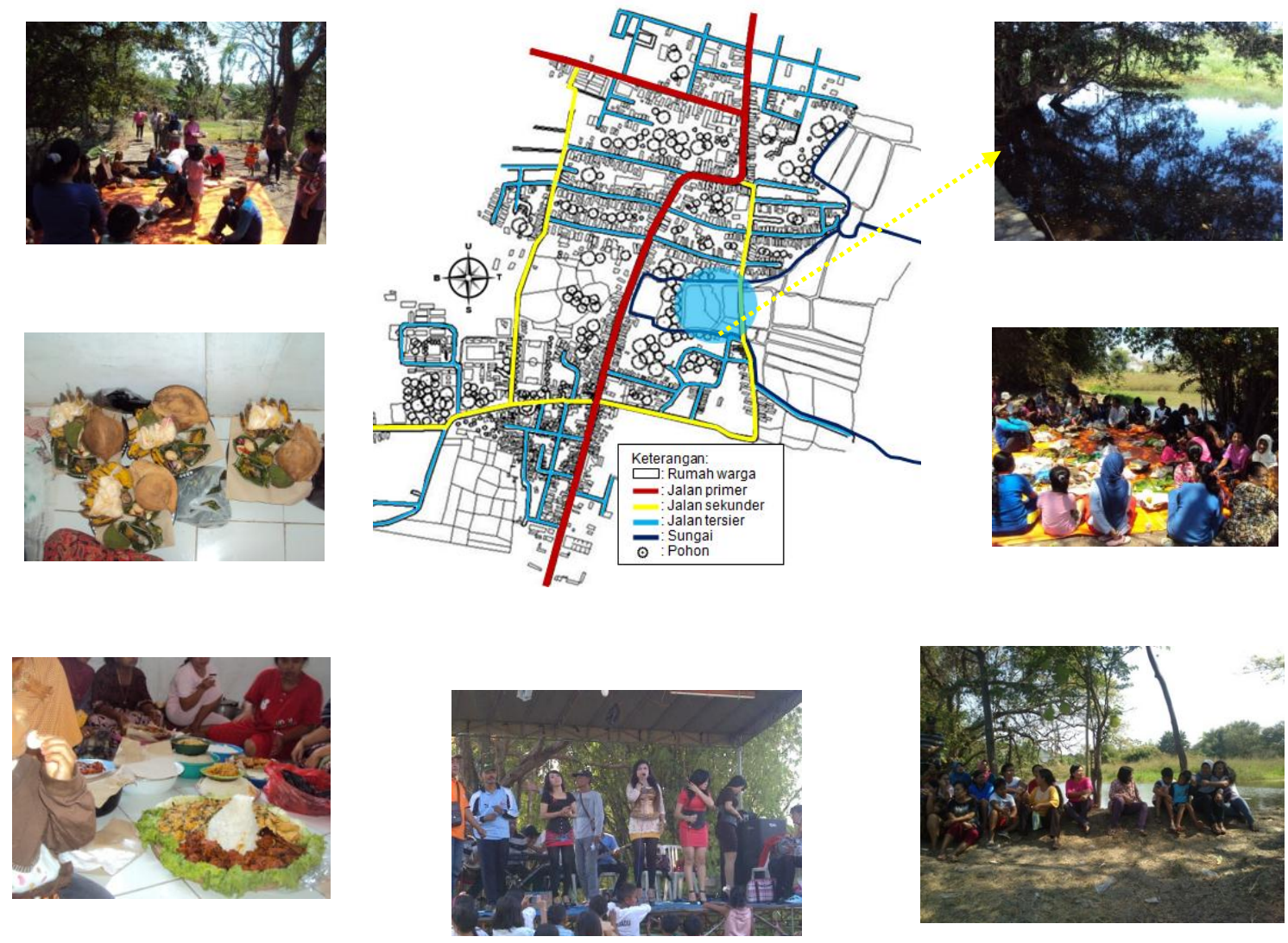

Gambar 5. Lokasi Studi Telaga Desa Cerme Kidul

Kegiatan dilanjutkan dengan berdoa. Kegiatan ini menjadi bagian terpenting, karena merupakan unsur yang selalu ada dalam setiap upacara keagamaan. Doa yang dilantunkan dalam upacara Sedekah Bumi adalah membaca tahlil dan diakhiri dengan doa memohon keselamatan. Pembacaan doa ini bertujuan untuk memohon kepada Tuhan Yang Maha Esa agar arwah Joko Umbaran (Mbah Dermo) diampuni dosa-dosanya dan warga Desa Cerme Kidul diberi keselamatan, dimudahkan rejekinya dan dijauhkan dari segala marabahaya.

Pada pagi hari ibu-ibu mempersiapkan masakan yang akan dibawa ke Sedekah Bumi, pukul 10.00 warga berbondong menuju Punden Telaga dengan membawa sesaji dan tumpeng masing-masing. Sesampainya di telaga warga duduk bersila saling berhadapan sejajar dan dibatasi tumpeng nasi putih, ayam panggang dan buah-buahan, secara sukarela para warga yang mengikuti acara sedekah bumi memberi wajib (uang) sekedarnya kepada sesepuh desa sebagai tanda mengikuti acara dan supaya ikut didoakan kepada nenek moyangnya. Acara diawali dengan sambutan ketua Panitia, dilanjutkan dengan sambutan Kepala Desa. Setelah itu membaca tahlil bersama-sama yang dipimpin oleh Juru Kunci Punden Telaga, dilanjutkan pembacaan doa. Usai pembacaan doa makan berkatan bersama-sama pun dimulai. 


\begin{tabular}{|c|c|c|c|c|}
\hline \multirow{3}{*}{\begin{tabular}{l}
\multicolumn{1}{c}{ leu } \\
Batasan area \\
ini adalah \\
ruang Telaga \\
untuk \\
kegiatan \\
Sedekah \\
Bumi. Ruang \\
yang \\
digunakan \\
adalah area \\
Punden, \\
pinggir telaga \\
dan jalan.
\end{tabular}} & Temporal & Perilaku & Synormorphic & Foto Setting \\
\hline & $\begin{array}{l}\text { Sabtu, } 6 \\
\text { September } \\
2014 \\
\text { Pkl. 08.00- } \\
09.30\end{array}$ & $\begin{array}{l}\text { Hasil } \\
\text { Observasi di } \\
\text { lapangan; Ibu- } \\
\text { ibu sedang } \\
\text { memasak lauk } \\
\text { pauk untuk } \\
\text { persiapan } \\
\text { Sedekah Bumi } \\
\text { di Telaga. }\end{array}$ & $\begin{array}{l}\text { Synormorphic } \\
\text { tercipta } \\
\text { apabila terjadi } \\
\text { antara pelaku } \\
\text { dengan milleu } \\
\text { sehingga } \\
\text { tercipta } \\
\text { aktivitas } \\
\text { pemanfaatan } \\
\text { ruang. }\end{array}$ & \\
\hline & $\begin{array}{l}\text { Pkl. 09.30- } \\
10.00\end{array}$ & $\begin{array}{l}\text { Warga yang } \\
\text { mengikuti } \\
\text { sedekah bumi } \\
\text { di Telaga satu } \\
\text { persatu } \\
\text { berjalan } \\
\text { menuju } \\
\text { Telaga. }\end{array}$ & $\begin{array}{l}\text { Sampel } \\
\text { menggunakan } \\
\text { ruangan } \\
\text { Telaga dan } \\
\text { lahan kosong } \\
\text { sebagai acara } \\
\text { Sedekah Bumi } \\
\text { dan Hiburan. }\end{array}$ & \\
\hline $\begin{array}{l}\text { Keterangan: } \\
\text { 1. Punden } \\
\text { Telaga } \\
\text { (pohon } \\
\text { lom) } \\
\text { 2. Warga } \\
\text { mengikuti } \\
\text { sedekah } \\
\text { bumi } \\
\text { 3. Warga }\end{array}$ & $\begin{array}{l}\text { Pkl. 10.00- } \\
11.00\end{array}$ & $\begin{array}{l}\text { Sampel 1; } \\
\text { warga yang } \\
\text { meyakini } \\
\text { adanya roh } \\
\text { penunggu } \\
\text { Punden diberi } \\
\text { sesaji berupa } \\
\text { takir. } \\
\text { Sampel 2; } \\
\text { sebanyak } 60 \\
\text { orang Bapak- } \\
\text { bapak, Ibu-ibu } \\
\text { dan anak- } \\
\text { anak, } \\
\text { bergabung } \\
\text { menjadi satu } \\
\text { tempat untuk } \\
\text { melaksanakan } \\
\text { sedekah bumi. }\end{array}$ & $\begin{array}{l}\text { Warga } \\
\text { memberi } \\
\text { sesaji sebuah } \\
\text { takir yang } \\
\text { berisi telor } \\
\text { ayam } \\
\text { kampung dan } \\
\text { kolo pendem } \\
\text { di bawah } \\
\text { punden telaga. }\end{array}$ & \\
\hline $\begin{array}{l}\text { mekan } \\
\text { berkatan } \\
\text { 4. Pangung } \\
\text { Hiburan } \\
\text { 5. Air telaga } \\
\text { 6. Tempat } \\
\text { undangan } \\
\text { Ibu-ibu } \\
\text { 7. Warga } \\
\text { menyaksik }\end{array}$ & $\begin{array}{l}\text { Pkl. 11.00- } \\
11.30\end{array}$ & $\begin{array}{l}\text { Sampel 2; } \\
\text { Nasi tumpeng } \\
\text { diletakkan di } \\
\text { bagian } \\
\text { tengah-tengah } \\
\text { yang dikitari } \\
\text { oleh warga } \\
\text { sambil duduk } \\
\text { bersila, } \\
\text { dilanjutkan }\end{array}$ & $\begin{array}{l}\text { Warga duduk } \\
\text { bersila } \\
\text { membentuk } \\
\text { lingkaran } \\
\text { untuk } \\
\text { mengikuti } \\
\text { Sedekah Bumi } \\
\text { yang dipimpin } \\
\text { oleh sesepuh } \\
\text { desa yang }\end{array}$ & \\
\hline
\end{tabular}




\begin{tabular}{|c|c|c|c|c|}
\hline $\begin{array}{l}\text { an hiburan } \\
\text { 8. Undangan } \\
\text { Bapak- } \\
\text { bapak } \\
\text { 9. Tempat }\end{array}$ & & $\begin{array}{l}\text { pembacaan } \\
\text { Do'a bersama } \\
\text { dipimpin oleh } \\
\text { Sesepuh Desa } \\
\text { setempat. }\end{array}$ & $\begin{array}{l}\text { bernama } \\
\text { bapak Pahing. }\end{array}$ & \\
\hline $\begin{array}{l}\text { parkir } \\
\text { kendaraan } \\
\text { 10.Pos } \\
\text { Kamling } \\
\text { 11.Tambak } \\
\text { 12.Jalan } \\
\text { Lingkunga } \\
\text { n } \\
\text { 13.Kebun }\end{array}$ & $\begin{array}{l}\text { Pkl. 11.00- } \\
11.45\end{array}$ & $\begin{array}{l}\text { Sampel 3; } \\
\text { setelah selesai } \\
\text { pembacaan } \\
\text { doa, maka } \\
\text { dimulainya } \\
\text { makan } \\
\text { berkatan dan } \\
\text { saling tukar } \\
\text { makanan. }\end{array}$ & $\begin{array}{l}\text { Warga } \\
\text { menikmati } \\
\text { nasi berkatan } \\
\text { bersama-sama } \\
\text { dengan } \\
\text { suasana } \\
\text { meriah. }\end{array}$ & \\
\hline $\begin{array}{l}\text { telaga } \\
\text { 14.Pohon dan } \\
\text { Rerumputa } \\
\text { n liar }\end{array}$ & $\begin{array}{l}\text { Pkl. 11.00- } \\
11.45\end{array}$ & $\begin{array}{l}\text { Sambutan } \\
\text { oleh Bapak } \\
\text { Kepala Desa } \\
\text { sebagai tanda } \\
\text { dimulainya } \\
\text { acara hiburan. }\end{array}$ & $\begin{array}{l}\text { Sambutan dari } \\
\text { bapak Kepala } \\
\text { Desa bahwa } \\
\text { acara Sedekah } \\
\text { Bumi di } \\
\text { Telaga dapat } \\
\text { dimulai. }\end{array}$ & \\
\hline & $\begin{array}{l}\text { Pkl. 11.45- } \\
16.30\end{array}$ & $\begin{array}{l}\text { Sampel 4; } \\
\text { Panggung } \\
\text { hiburan Orkes } \\
\text { Dangdut. }\end{array}$ & $\begin{array}{l}\text { Hiburan Orkes } \\
\text { Dangdut } \\
\text { sebagai acara } \\
\text { memeriahkan } \\
\text { acara Sedekah } \\
\text { Bumi di } \\
\text { Telaga. }\end{array}$ & \\
\hline
\end{tabular}

\section{Kesimpulan}

Desa Cerme Kidul sebagian besar masyarakatnya berprofesi sebagai petani, beragama Islam, unsur kepercayaan dan kejawen, sehingga ruang yang digunakan sebagai tradisi Sedekah Bumi adalah Telaga. Berdasarkan hasil penelitian Pemanfaatan Ruang Telaga Pada Tradisi Sedekah Bumi Desa Cerme Kidul dapat disimpulkan bahwa tradisi tersebut mempunyai nilai-nilai historis dari nenek moyang yang secara turun-temurun dilakukan setiap tahun untuk mensyukuri nikmat yang telah diterima dan sebagai rasa syukur maka dilakukan Tradisi Sedekah Bumi di bawah pohon Lom (Punden Telaga).

\section{Daftar Pustaka}

Arimbawa, Wahyudi,I Komang Gede Santhyasa. 2010. Perspektif Ruang sebagai Entitas Budaya Lokal, Orientasi Simbolik Ruang Masyarakat Tradisional Desa Adat Penglipuran Bangli Bali. Jurnal Local Wisdom. II(4):01-09. Laurens J. M. 2004. Arsitektur dan Perilaku Manusia. Jakarta: PT Grasindo. Zeisel, John. 1981. Inguiry By design: Environment / Behaviour / Neuroscience in Architecture, Interiors, Landscape, and Planning. California: Wadsworth, Inc., Belmont. 